\title{
CHALLENGES OF AGRICULTURAL COOPERATIVES AND THEIR IMPACT ON PROFITABILITY OF POTATO GROWERS IN EASTERN ETHIOPIA
}

\author{
Yonas Abera MAMO ${ }^{1 *}$ (D), Jema HAJI ${ }^{2}$ (D), Belaineh LEGESSE ${ }^{2}$ (iD), Maria SASSI ${ }^{3}$ (D)
}

\author{
Address: \\ ${ }^{1}$ Department of Economics, College of Business and Economics, Dire Dawa University, P.O.Box 1362, Dire Dawa, \\ Ethiopia \\ ${ }^{2}$ Department of Agricultural Economics, College of Agricultural Economics and Agribusiness, Haramaya University, \\ P.O.Box 138, Haramaya, Ethiopia \\ ${ }^{3}$ Department of Economics and Management, University of Pavia, Via. S. Felice 5, 27100 Pavia, Italy \\ * Corresponding author: aberayonas2004@gmail.com
}

\begin{abstract}
Background of the research: Agricultural cooperatives are established for the sake of improving the livelihood of smallholder farm households through improving their profitability. However, due to several challenges facing the cooperatives, their establishment may not guarantee such an achievement. Hence, it is essential to empirically verify their impact on profitability of the smallholder farm households.

Purpose of the article: The purpose of this study is to measure the impact of agricultural cooperatives on profitability of small holder potato farmers in Eastern Ethiopia.

Methods: The study was conducted making use of survey data on members and non-members of agricultural cooperatives in Eastern Hararghe based on multi-stage sampling method. Simple inferential and econometric methods of data analyses were carried out. The simple inferential analysis involves mean comparison tests whereas the econometric analysis is related to PSM method along with simulation-based sensitivity analysis.

Findings and value added: The inferential analysis indicates that there is no significant difference in per unit profit between members and non-members. This result also holds true with disintegration of components of the profitability into per unit price, per unit cost of production and per unit cost of marketing. The PSM result also shows that, except the slightly significance for per unit cost of production in favour of non-members, there is no significant difference in terms of per unit profit, per unit price, and per unit cost of marketing. The result implies that membership to cooperatives does not guarantee positive impact on profitability of its members.

Recommendation: Therefore, it is recommended that strict follow-up is crucial on the cooperatives' performance; agricultural cooperatives better be functional in all aspects attached to profitability of farmers; active participation of member farmers is inevitable; frequent and regular trainings are also necessitated in order to build the managerial capacity of the leaders; and there should be clear framework of coordination in production and marketing activities. The other mentioned challenges should also be considered.
\end{abstract}

Key words: agricultural cooperatives; profitability; impact; PSM; potato JEL Codes: D43; L13; Q13; Q18

\section{INTRODUCTION}

Ethiopia is one of the developing countries for which agriculture is considered as the mainstay of the economy. Different studies show that in Ethiopia agriculture is the dominant sector of economic activity; in which majority of the people are engaged; contributing slightly less than half of GDP; and known to be the main source of foreign currency (Matousa et al., 2013). However, majority of the people engaged in this sector are smallholder farmers who lead their livelihood with subsistence agriculture. This sector also accompanied with a number of challenges like low level of productivity; lower land size; lack of adequate knowledge and information transfer; slow return of benefit and lack of financial support; lack of improved seed and others (Habtewold \& Challa, 2019; Zerssa et al, 2021). The prevalence of this subsistence agriculture has the tendency to prolong impoverishment of majority of the people.

The development in the agricultural sector is believed to have spillover effects for the development of the economy as a whole, in terms of enhancing food security resulting from the rise in productivity of the agricultural sector. In regard to the importance of agriculture in a broader socio-economic sense, all the basic objectives of economic development of the country, namely, output 
growth, price stability and poverty alleviation are best served by growth of the agriculture sector. This is expected to be realized if public investment and market infrastructure in agriculture are adequate (MSPII, 2010). In cognizant of this, the government has been formulating different policies related to commercialization of agricultural sector. Government's emphasis on a strong agricultural development led industrialization policy for sustained economic growth implies transforming traditional agriculture into a commercial agriculture. Toward that objective, a number of policies have been implemented in order to remove bottlenecks that had contributed to stagnation in yield and production in agriculture in the past (Getnet et al., 2005).

African countries' experience like Ethiopia indicates that the agricultural research and development organizations have made significant progress on increasing agricultural productivity. But, sustainability of productivity and growth of the agricultural sector depends on expansion of market opportunities (Gabre-Madhin \& Haggblade, 2004). Hence, it is now increasingly evident that smallholder farmers' key concern is not only agricultural productivity and household food consumption, but also increasing better market access. Agricultural research and development organizations are now under pressure to shift from enhancing productivity of food crops to improving profitability and competitiveness of small-scale farming, and linking smallholder farmers to more profitable markets (Njuki $\boldsymbol{e t}$ al., 2015).

However, the profitability and competitiveness of the smallholder farmers is determined by the efficiency of the market. In more competitive markets, there are lower marketing costs, better prices for farmers and consumers, and more efficient market services thereby the virtues of agricultural marketing are realized (Njuki et al., 2015). Despite the fact that market for agricultural sector is believed to be an engine for economic growth and development, its effectiveness relies on the functioning of the market system. In a well-functioning market system, all economic agents have equal market participation and thereby generate fair and mutual benefit (Barrett \& Li, 2002). However, market functioning system of agricultural sector is adversely affected by a number of factors which may limit the market participation of some agents (especially smallholder farmers) and their benefits.

It is argued that the agricultural marketing system in Ethiopia has several difficulties that specifically limit the market participation of smallholder farmers. These difficulties consist smallholders' lack of access to markets, high transaction costs resulted from low volume of transactions, supply rigidity due to perishability of agricultural products, instability of prices, inequity of prices due to producers' lack of information, frequent frauds on input quality and units of measurement, poor productivity potential due to lack of investment and farmers' aversion of risks (Bienabe and Sautier, 2006)

The agricultural marketing system in Ethiopia also tends to be informal, unregulated and constrained by weak market linkages and lack of rural infrastructure. In the remote rural markets, producers suffer from high transaction costs in terms of searching, negotiation and transportation. Furthermore, transactions are thin that weaken the market power of smallholder producers. The absence of institutions in supplying information and facilitating exchange exacerbate the smallholders' market problem and expose producers to sell their products to traders who have high opportunistic buying behaviour. This constrained the participation of agricultural producers and gain relatively lower benefits from the market mechanisms (Gabre-Madhin, 2001).

In order to coup-up with these challenges, among policy enactments, agricultural cooperatives were established in the sense of empowering the smallholder farmers. Historically, agricultural cooperatives are said to have played an important role all over the world in providing market access, credit and information to producers/farmers. In particular, agricultural cooperatives have played an important economic role in providing competitive returns for independent farmers (Chaddad $\boldsymbol{e t}$ al., 2005). Cooperatives, as economic enterprises and as self-help organizations, play a meaningful role in uplifting the socio-economic conditions of their members and their local communities. The social role of cooperatives is promoted through voicing of common goals, enhanced participation in value chains, and protection of producers from unfair pricing. Cooperatives also create opportunity for networking and working in partnership with other agencies (Argaw, 2019).

Generally, Barker (1989), states that the theoretical basis for such cooperation is related to three major factors. These are bargaining power (increasing farmers' bargaining strength), marketing economies (reducing the cost of marketing by improving the efficiency of existing services, or achieving scale economies in certain operations), and market investment (providing an additional investment opportunity in marketing of commodities covered by the cooperative).

In Ethiopia, the government has strongly promoted agricultural cooperatives to encourage smallholders' participation in the market (Bernard et al., 2008). Currently agricultural cooperatives in the country are assumed to play significant role that are mainly able to insure the benefits of the member farming rural community through effective value chain development and market linkage. In terms of market linkage, for instance, in SNNPR, WFP-P4P program buys agricultural products from the market cooperatives which creates greater opportunity in terms of improving the bargaining power position of members and thus guarantee their benefit from what they have produced. This is due to cutting the very long and inefficient chain, the significance of the business volume made with the program, and motivation of the market by realizing domestic purchase of grain that would have been imported as a relief or emergency support (Argaw, 2019).

However, agricultural cooperatives are also said to have a number of drawbacks which may hamper the benefit of farmers from the market. In addition, agricultural cooperatives may face problems such as conflict of interest among members, inadequate level of education and training of members, exploitation of members by dishonest members, lack of effective leadership, excessive government control, poor 
capitalization, lack of total commitment by members, inadequate and ill-timed supply of inputs by some members, and poor capitalization (Llebani, 2010).

Farmers under agricultural cooperatives are also expected to bear additional costs of transaction to manage transactions as membership. Perhaps, their net gain from the market can be relatively higher or lower depending on the extent of benefit derived from the cooperation. In this regard, Hendrikse \& Veerman (2000) state, based on theory of transaction cost economics, that cooperatives are not advocated when the degree of asset specificity by the farmers is low because it increases the bureaucratic costs of exchange within a firm. In this case, farmers should opt for the best alternative market based on their product differentiation, individually.

Moreover, within the conception of theory of transaction cost economics, Ortmann \& King (2007) identify five problems of cooperatives. These include: free rider problem (a type of common property problem that emerges when property rights are not tradable or are not sufficiently well defined and enforced to ensure that individuals bear the full cost of their actions or receive the full benefits they create), horizon problem (when a member's residual claim on the net income generated by an asset is shorter than the productive life of that asset), portfolio problem (members are unable to diversify their individual investment portfolios according to their personal wealth and preferences for risk taking), control problem (principal-agent problems due to divergence of interests), and influence cost problem (costs associated with activities in which members or groups within an organization engage in an attempt to influence the decisions that affect the distribution of wealth or other benefits within an organization).

Given these possible pros and cons of agricultural cooperatives, it is crucial to empirically investigate the real impact of their existence on profitability of farmers. Perhaps, in Ethiopia, there are few previous empirical studies, in this regard. These studies focus on analyses of productivity performance of cooperatives and measurement of their impact on technical efficiency of farmers (Abate et al., 2014), on wellbeing of smallholder farmers (Ahmed and Mesfin, 2017) and on economy (Debela et al, 2018). All these past works disregard the importance of the interplay of the market. Specifically, they have overlooked analysis of the impact of existence of the cooperatives on profitability of the smallholder farmers. Therefore, this study attempts to fill this gap by conducting an empirical study on the impact of participation in agricultural cooperatives on the net gain of farmers, as well as to identify and rank the major challenges facing them. The study was conducted making use of potato growers in Eastern Ethiopia (Eastern Hararghe Zone).

\section{LITERATURE REVIEW}

Theories of market-oriented agricultural cooperatives and their empowering role for smallholder farmers

Historically, agricultural cooperatives are said to have played an important role all over the world in providing market access, credit and information to producers/farmers. In particular, agricultural cooperatives have played an important economic role in providing competitive returns for independent farmers (Chaddad $\boldsymbol{e t}$ al., 2005). The rationale behind establishing marketoriented cooperatives is that farmers generally market their crops to large, highly organized, commodity merchant firms or to large processing firms. Since these firms combine expertise and capital, farmers should be allowed to develop their own marketing firms in order to compete with them on equal footing (Branson \& Douglass, 1983). According to Staatz (1989), they were established as service providers and were primarily aimed at countervailing the market power of producers' trading partners, preservation of market options and reduction of risk through pooling.

Cooperatives are known to be member-owned businesses. They aggregate the market power of people who on their own could achieve little or nothing, and in so doing they provide ways out of poverty and powerlessness. Cooperatives, as economic enterprises and as self-help organizations, play a meaningful role in uplifting the socio-economic conditions of their members and their local communities. The social role of cooperatives is promoted through voicing of common goals, enhanced participation in value chains, and protection of producers from unfair pricing. Cooperatives also create opportunity for networking and working in partnership with other agencies (Argaw, 2019).

Generally, Barker (1989), states that the theoretical basis for such cooperation is related to three major factors. These are bargaining power (increasing farmers' bargaining strength), marketing economies (reducing the cost of marketing by improving the efficiency of existing services, or achieving scale economies in certain operations), and market investment (providing an additional investment opportunity in marketing of commodities covered by the cooperative).

In Ethiopia, the government has strongly promoted agricultural cooperatives to encourage smallholders' participation in the market (Bernard et al., 2008). Currently agricultural cooperatives in the country are assumed to play significant role that are mainly able to insure the benefits of the member farming rural community through effective value chain development and market linkage. In terms of market linkage, for instance, in SNNPR, WFP-P4P program buys agricultural products from the market cooperatives which creates greater opportunity in terms of improving the bargaining power position of members and thus guarantee their benefit from what they have produced. This is due to cutting the very long and inefficient chain, the significance of the business volume made with the program, and motivation of the market by realizing domestic purchase of grain that would have been imported as a relief or emergency support (Argaw, 2019).

However, market cooperatives are also said to have a number of drawbacks which may hamper the benefit of farmers from the market. Marketing cooperatives may face problems such as conflict of interest among members, inadequate level of education and training of members, exploitation of members by dishonest members, lack of effective leadership, excessive government control, poor 
capitalization, lack of total commitment by members, inadequate and ill-timed supply of inputs by some members, and poor capitalization (Llebani, 2010).

Farmers under agricultural cooperatives are also expected to bear additional costs of transaction to manage transactions as membership. Perhaps, their net gain from the market can be relatively higher or lower depending on the extent of benefit derived from the cooperation. In this regard, Hendrikse \& Veerman (2000) state, based on theory of transaction cost economics, that cooperatives are not advocated when the degree of asset specificity by the farmers is low because it increases the bureaucratic costs of exchange within a firm. In this case farmers should opt for the best alternative market based on their product differentiation, individually. However, exchange in markets (without cooperatives) becomes problematic when the level of asset specificity is increasing due to the increasing prominence of hold-up problem among market participants.

Moreover, within the conception of theory of transaction cost economics, Ortmann \& King (2007) identify five problems of cooperatives. These include: free rider problem (a type of common property problem that emerges when property rights are not tradable or are not sufficiently well defined and enforced to ensure that individuals bear the full cost of their actions or receive the full benefits they create), horizon problem (when a member's residual claim on the net income generated by an asset is shorter than the productive life of that asset), portfolio problem (members are unable to diversify their individual investment portfolios according to their personal wealth and preferences for risk taking), control problem (principal-agent problems due to divergence of interests), and influence cost problem (costs associated with activities in which members or groups within an organization engage in an attempt to influence the decisions that affect the distribution of wealth or other benefits within an organization).

\section{Empirical studies on impact of marketing cooperatives for smallholder farmers}

Theoretically, agricultural market cooperatives are said to play an immense role in reducing poverty among smallholder farmers by correcting market failure. They are established to make smallholder farmers capable while confronting with the prevailing higher marketing transaction costs, limited access of finance and input markets, and risk of price fluctuations (Blokland $\boldsymbol{\&}$ Gouet, 2007). However, some believe that cooperatives may bring about contradictive outcomes on the welfare of the farmers for a number of reasons (Ruben \& Heras, 2012). Hence, the positive or adverse role of the cooperatives can only be confirmed using empirical studies. To this end, in Ethiopia, various empirical works were undertaken to show the practical role of agricultural cooperatives in different places, which came up with different results.

Kodama (2009) has shown that agricultural cooperatives can have a wider effect to the extent that their spillover effects provide benefit for non-members as well. $\mathrm{He}$ has empirically indicated that, by increasing competition, the activities of coffee cooperatives in
Ethiopia have generally increased the prices paid to both member and nonmember farmers. Besides, with the existence of the cooperatives, the export volume of fairtrade coffee has also increased and has helped buffer fair trade coffee farmers from international price fluctuations.

However, there are studies revealing that some cooperatives are not performing well. In this regard, there are studies showing that better off farmers prefer to sale their produce through traders than cooperatives due to the inefficiency of cooperatives. Kuma et al (2013) have empirically shown that the likelihood of accessing cooperative milk market outlet, in Wolaita zone of Ethiopia, was lower among households who owned large number of cows.

In fact, in a given place, different types of cooperatives can have different levels of performance due to different reasons. Ruben \& Heras (2012) have compared the activities of coffee cooperatives in Sidama zone based on their level of social capital and governance structure. Their findings indicate that the cooperatives of Kege and Magerra present significantly lower levels of social capital shared by their members compared to the better performing cooperative societies of Waycho, Shoye and Goyda. This is because the former are situated close to the main road and near to the Woreda township whereas the latter are located at the considerable geographic distance. Having better social capital means better access to markets and information, and proximity to road reduces the external transaction costs.

With regard to the differences in governance structure, they have shown that in Kege and Magerra cooperatives, the participation in assembly meetings and the coffee deliveries by members are indeed significantly lower. Consequently, cooperative profits and traded volumes are highly dependent on members' commitment for devoting time and resources to coffee production and delivering coffee to the cooperative society. Moreover, Kege and Magerra cooperatives present a very low and distant feelings of ownership regarding their organization, whereas in the other three cooperatives members instead share strong feelings of opposition against the committee that are reflected in active participation in the assemblies and stronger involvement in cooperative affairs. This is further reinforced by the fact that Waycho, Shoye and Goyda cooperatives are eligible for bank loans and can thus provide early payments for coffee deliveries (Ruben \& Heras, 2012).

So far, we have presented more about the performance of the cooperatives in terms of their own efficiency or strength. However, it is also crucial to see the impact of these organizations on the farmers' livelihood. As far as our knowledge, in Ethiopia, it is only Abate et al. (2013) who have undertaken a study related to this specific aspect (impact assessment). Abate et al. (2013), in their investigation of the impact of agricultural cooperatives on small holders' technical efficiency in Ethiopia, have shown that agricultural cooperatives are effective in providing support services that significantly contribute to members' technical efficiency.

However, this result does not necessarily imply that cooperatives improve profitability of member farmers since their study focuses on efficiency of the use of inputs, 
which does not consider the feature of pricing of final outputs in particular and the interplay of the market in general. In other words, there may be a situation where farmers are technically efficient but they face unfair price for their final output due to market failure. In consideration of this gap, this inquiry will give much focus towards the impact of the cooperatives on profitability of farmers, giving due attention to the interplay of the market. In addition, in this study, an attempt will be made to identify the major marketing challenges facing the market oriented agricultural cooperatives in general and the farmers in particular.

\section{DATA AND METHODS}

\section{Description of the Study Area}

East Hararghe is one of the Zones of the Region of Oromia found in Eastern part of Ethiopia. East Hararghe takes its name from the former province of Hararghe. East Hararghe is bordered on the southwest by the Shebelle River which separates it from Bale, on the west by Western Hararghe, on the north by Dire Dawa and on the north and east by the Somali Region. The Harari Region is an enclave inside this zone. The Administrative center of this zone is Harar.

In eastern Hararghe (Oromia region), all types of agro-ecological zones (Kola, Dega and Weyna Dega) exist having both highland and lowland societies. The mean annual rainfall varies from lowland to highland. It has two rainy seasons for agricultural production which are known to be "Belg"/Autumn (covers months of September, October and November which is known to be more of a harvest season) and "Kiremt"/Summer (which is the rainiest season that covers months of June, July and August) seasons. Output is expected to be higher during "Kiremt" and "Belg" season than that of the dry seasons including "Bega"/Winter (covers December, January and February which is the dry season with frost in morning specially in January). and "Tseday"/Spring (covers March, April and May are the autumn season with occasional showers). May is the hottest month in Ethiopia seasons. Hence, prices of the produce are expected to show ups and downs across these seasons and places (UNDP-EUE, 1994).

Based on the 2007 Census conducted by the Central Statistical Agency of Ethiopia (CSA), this Zone has a total population of $2,723,850$, an increase of $48.79 \%$ over the 1994 census, of whom 1,383,198 are men and 1,340,652 women; with an area of 17,935.40 square kilometers. East Hararghe has a population density of 151.87. While 216,943 or $8.27 \%$ are urban inhabitants, a further 30,215 or $1.11 \%$ are pastoralists. A total of 580,735 households were counted in this Zone, which results in an average of 4.69 persons to a household, and 560,223 housing units.

Production in Eastern Hararghe zone is based on roughly $70 \%$ crops and $30 \%$ on livestock. Major cash crops grown in Eastern Hararghe include khat, coffee, onion, haricot beans, groundnuts, mangos, sweet potato, potatoes and other types of fruits and vegetables. Generally, the dominant cash crops in the area were found to be khat, coffee and vegetables (UNDP-EUE, 1994).
Of vegetables, potato production takes the largest share in some areas such as Kombolcha and Haramaya (Piguet, 2003). Hararghe, in eastern Ethiopia is one of the major potato producing regions of the country and potato is grown in both the rainy and dry season. The presence of regional and domestic markets around nearby cities as well as exports to neighbouring countries such as Djibouti and Somalia have contributed to the development of potato production in Hararghe highlands (Adane et al., 2010).

The Woredas found in East Hararghe zone include Fedis, Babile, Jarso, Kombolcha, Kersa, Haramaya, Meta, Deder, Gursum, Kurfachele, Gorogutu, Bedeno, and Garamuleta. From these Woredas, Haramaya and Kombolcha were selected as the study areas since these areas are the major producers and suppliers to local and export markets.

\section{Data Type, Sources and Methods of Data Collection}

The type of data required to undertake this study is crosssectional. Sources of data for this inquiry are both primary and secondary. The primary data was collected using survey on farm households whereas the secondary data were extracted from books, articles, and published and unpublished documents of offices of agriculture and cooperatives. The primary method of data collection in this study was questionnaires/schedule method. To this end, 12 Development Agent (DA) workers were recruited as enumerators for the data collection. Besides, Focus Group Discussions (FGDs) were held with concerned officials from offices of Agriculture and Cooperatives.

\section{Sampling Procedure}

In this study, multi-stage sampling method was applied. In the first stage the two Woredas (Haramaya and Kombolcha) were selected as specific study areas purposively as these are the major suppliers of the crop. In the second stage, four Kebeles (which are much closer to irrigation for production of vegetables including potato) from which the farm households to be drawn were selected purposively based on consultation with expertise from Offices of Agriculture of the two Woredas. These include: Tinike, Tuji Gabisa, Kerensa, and Bilisuma. In third stage, potato grower households, in each Kebele, were clustered into cooperative members and non-members. Finally, the farm households which are using irrigation were selected (from both members and non-members of agricultural cooperatives) randomly using probability proportional to size (PPS). Accordingly, the total sample size taken for the study is 300 (102 from members and 198 from nonmembers).

\section{Data Analysis Methods}

To undertake this study, descriptive, inferential statistics and econometrics methods of analyses were carried out. The descriptive and inferential analysis involves comparison of per unit profit, per unit price, per unit cost of marketing and per unit production cost for members (treated group) and non-members (control group) making use of mean comparison test. Apart from this, Likert scale was used to assess the severity of challenges facing the cooperatives. 
The econometric analysis is used to measure the impact of participation in agricultural cooperatives on net gain of farmers through application of Propensity Score Matching Method (PSM). This method involves the following five major steps.

A. Estimation of the propensity score for each household

B. Choice of matching algorithm

C. Test of overlap assumption

D. Estimating the average treatment effect on the treated

E. Sensitivity analysis

\section{Estimation of propensity scores}

In technical terms, suppose there are two types of farmers: those that are members of cooperatives $D_{i}=1$ and those that do not $D_{i}=0$. Members (treated group) are matched to those non-members (comparison group) on the basis of the propensity score. The propensity score (p-score) for individual $i$ is defined as Eq. 1 .

$$
P\left(X_{i}\right)=P\left(D_{i}=1 \mid X_{i}\right)
$$

\section{Where:}

$0<P\left(X_{i}\right)<1$ and $X_{i}$ is a vector of pre-treated explanatory variables such as farmers characteristics.

A probit or logit model can be used to estimate the propensity score using composite pre-intervention characteristics of the sample households (Caliendo \& Kopeining, 2005). In this study, we primarily employed the logit model to estimate the p-score. In the specification of the logit model, the dependent variable is the probability to be member of cooperatives by the farmers. The logit model is specified as Eq. 2.

$P(D=1 \mid X)=\frac{e^{W_{i}}}{1+e^{W_{i}}}$

$W_{i}=\beta_{0}+\beta_{1} X_{1 i}+\beta_{2} X_{2 i}+\cdots \beta_{m} X_{m i}+v_{i}$

Where:

$P(D=1 \mid X)$ is the probability that an individual is a member of cooperative given $X ; X_{S}$ represent the explanatory variables; $\beta_{S}$ denote the parameters to be estimated; and $v$ is the residual term. Descriptions of the variables considered for estimation of the logit model are stated with their hypothetical relationship, in Table 1.

$Y_{i, t+s}(1)-Y_{i, t+s}(0)$

Finally, existing studies on impact evaluation often estimate the average effect of the treatment on the treated (ATT), defined as Eq. 4.

$$
\begin{aligned}
& A T T=E\left(Y_{i, t+s}(1)-Y_{i, t+s}(0) \mid D_{i t}=1, P\left(X_{i}\right)_{i, t-1}\right)= \\
& E\left(Y_{i, t+s}(1) \mid D_{i t}=1, P\left(X_{i}\right)_{i, t-1}\right)- \\
& E\left(Y_{i, t+s}(0) \mid D_{i t}=1, P\left(X_{i}\right)_{i, t-1}\right)
\end{aligned}
$$

Where:

$X_{i}$ denotes pre- program characteristics of individual $\mathrm{i}$ in year t-1;

$P\left(X_{i}\right)$ is the $p$-score;
$Y_{i}^{1}$ and $Y_{i}^{0}$ are the potential outcomes in the two counterfactual situations of receiving treatment and no treatment.

\section{Sensitivity analysis}

The legitimacy of p-score analysis is based on the assumption of strongly ignorable treatment assignment which assumes all relevant covariates are employed in the treatment assignment and the bias due to the unmeasured covariates is ignorable (Thoemmes \& Kim, 2011). If the estimated treatment effect is sensitive to the presence of unmeasured covariates, or in other words, the estimated treatment effect is possibly washed away with the unmeasured covariates, the treatment effect may be due to the bias of unobserved covariates rather than a true effect. On the other hand, if a considerable magnitude of unobserved covariate effect is not likely to mitigate the treatment effect, researchers gain confidence on the treatment effect as an unbiased estimate (Lanehart et al., 2012).

Lanehart et al. (2012) specifies the re-estimation of the treatment effect given the unmeasured covariates $(U)$ as Eq. 5.

$\delta^{*}=\delta-\gamma\left(E\left[U_{1}\right]-E\left[U_{0}\right]\right.$

Where:

$\delta$ is the treatment effect after controlling for the observed covariates, $E\left[U_{1}-E\left[U_{0}\right]\right.$ is the effect of unobserved covariates, and $\delta^{*}$ is the adjusted treatment effect. That is, the adjusted treatment effect can be obtained by removing the hidden bias due to unmeasured covariates from the estimated treatment effect.

Sensitivity analysis is a type of what-if analysis because the effects of unmeasured covariates with two sensitivity parameters $\left(\gamma\right.$ and $E\left[U_{1}\right]-E\left[U_{0}\right]$ are not empirically estimable. The proxy of sensitivity parameters can be obtained either from the observed data or from theory and literature (Li et al., 2011). Ichino et al. (2006) propose simulation-based sensitivity analysis to assure the robustness of the result (see also Nannicini, 2007 and Arpino \& Assve, 2013). The analysis builds on Rosenbaum \& Rubin (1983) and Rosenbaum (1987), and simulates a potential binary confounder in order to assess the robustness of the estimated treatment effects with respect to specific deviations from the Conditional Independence Assumption (CIA). The procedure is explained as follows:

As a first step, the Average Treatment effect on the Treated (ATT) is estimated by using one of the following propensity score matching estimators: Nearest Neighbor (attnd, attnw); Radius (attr); Kernel (attk). The options that are common to these commands specify how the baseline ATT is estimated. As a second step, a potential binary confounder $(U)$ is simulated in the data, on the basis of four parameters: $P_{i j}$ (with $i, j=0,1$ ). Defining $Y$ as the outcome (or as a binary transformation of the outcome in the case of continuous outcomes) and $D$ as the binary treatment, each simulation parameter $P_{i j}$ represents the probability that $U=1$ if $D=i$ and $Y=j$. Finally, $U$ is considered as any other covariate and is included in the set 
of matching variables used to estimate the propensity score and the ATT.

The imputation of $U$ and the ATT estimation are replicated many times, and a simulated ATT is retrieved as an average of the ATTs over the distribution of U. This estimate is robust to the specific failure of the CIA implied by the parameters $\mathrm{p}_{\mathrm{ij}}$. A comparison of the simulated ATT and the baseline ATT tells us to what extent the latter is robust, with respect to the specific deviation from the CIA that we are assuming. In order to further emphasize the characteristics of the failure of the CIA implied by the simulated confounder (i.e., by the chosen $P_{i j}$ ), the estimated effect of $U$ on the selection into treatment selection effect $(\Lambda)$ - and the estimated effect of $U$ on the outcome of untreated subjects - outcome effect $(\Gamma)$ - are also reported as odds ratios.

As indicated in Arpino \& Aassve (2013), the distribution of $U$ is specified by four key parameters (Eq. 6).

$P_{i j}=P(U=1 \backslash D=i, Y=j)=P(U=1 \backslash D=i, Y=$

$j, X) \quad i, j=0,1$

Hence, the possibilities of the effect of $U$ on outcome $(Y)$ and treatment $(D)$ is determined by the values of $d=$ $P_{01}-P_{00}$ and $s=P_{1}-P_{0}$, where $P_{i}=P(U=$ $1 \mid D=i)$. If $d>0, U$ has a positive effect on $Y_{0}$ (conditioning on $X$ ) whereas if $s>0$, then $U$ has a positive effect on $D$. Note that $P_{01}$ is the probability that $U=1$ given $D=0$ and $Y=1 ; P_{00}$ is the probability that $U=1$ given $D=0$ and $Y=0 ; P_{10}$ is the probability that
$U=1$ given $D=1$ and $Y=0$; and $P_{11}$ is the probability that $U=1$ given $D=1$ and $Y=1$.

\section{RESULTS AND DISCUSSION}

\section{Descriptive Comparative Analysis}

In this part, comparison of per unit profit between treated and control groups carried out making use of mean comparison test. In order to disintegrate the main source of the difference in profitability of the farmers, comparisons were also made in terms of per unit production cost, per unit marketing cost and per unit price between the two groups. It is obvious that profitability of the farmers is related to production (reduction in cost of farming) or/and marketing (reduction in cost of marketing or getting higher price for the produce).

As indicated in Table 2, per unit cost of production between the two groups looks similar which is revealed by the significance test of difference. As shown in the Table 2 , the t-value is very lower confirming that there is no significant difference in cost of production between the two groups at even $10 \%$ level of significance. The implication of this is that, if there is significant difference in per unit profit between the two groups, it must emanate from the interplay of the market (i.e. it is due to either the difference in costs of marketing or the difference in price of the product or both). However, this preliminary result also shows that there is no difference in per unit marketing cost and per unit price. The $t$-values for both of these variables are very smaller for significance.

Table 1: Description of the variables considered for the logit model

\begin{tabular}{|c|c|c|c|}
\hline Name of the variable & Type of the variable & Description (unit of measurement) & $\begin{array}{l}\text { Hypothetical } \\
\text { relationship } \\
\text { with the } \\
\text { dependent } \\
\text { variable }\end{array}$ \\
\hline $\begin{array}{l}\text { Dependent Variable: Membership of } \\
\text { agricultural cooperatives }\end{array}$ & Dummy & Not member $=0 ;$ Member $=1$ & \\
\hline Age of the household head & Continuous & Years & $+/-$ \\
\hline Education level & Dummy & Illiterate $=0 ;$ Literate $=1$ & + \\
\hline $\begin{array}{l}\text { Experience (in years) of the household } \\
\text { head in potato production }\end{array}$ & Continuous & Years & + \\
\hline Family size & Continuous & Number & + \\
\hline Farm size & Continuous & $\mathrm{Ha}$ & + \\
\hline Proportion of farm income & Continuous & Farm income/Total income & + \\
\hline Quantity of potato production sold & Continuous & Kgs & + \\
\hline Access to market information & Ordered variable & $\begin{array}{l}\text { No access }=1 ; \text { Little access }=2 ; \\
\text { Satisfactory }=3 ; \text { Good }=4 ; \text { Very good } \\
=5\end{array}$ & - \\
\hline Access to extension services & Dummy & Not provided $=0 ;$ Provided $=1$ & + \\
\hline $\begin{array}{l}\text { Distance to the nearest urban center } \\
\text { (market) }\end{array}$ & Continuous & $\mathrm{Kms}$ & + \\
\hline Distance to the nearest asphalt road & Continuous & Kms & + \\
\hline Location/Woredea & Dummy & Kombolcha $=0 ;$ Haramaya $=1 ;$ & indeterminate \\
\hline Access to credit & Dummy & Doesn't have $=0 ;$ Have $=1$ & - \\
\hline Political participation & Dummy & Doesn't participate $=0 ;$ Participates $=1$ & + \\
\hline Yield of potato production & Continuous & $\mathrm{kg} / \mathrm{ha}$ & + \\
\hline
\end{tabular}


Table 2: Comparison of per unit profit, per unit cost of production, per unit marketing cost and per unit price between the members and non-members

\begin{tabular}{llrll}
\hline Variable & Group & Mean & Std. Error & t-value \\
\hline Per unit cost of production & Non-member & 1.441348 & 0.0498988 & -1.3805 \\
& Member & 1.565893 & 0.0801442 & \\
Difference & -0.1245454 & 0.0902197 & \\
Per unit profit & Non-member & 4.162862 & 0.0883085 & 0.8935 \\
& Member & 4.030784 & 0.1141284 & \\
Per unit marketing cost & Difference & 0.1320781 & 0.1478224 & \\
& Non-member & 0.5400571 & 0.0212221 & -1.1859 \\
& Member & 0.954714 & 0.4861789 & \\
Per unit price & Difference & -0.4146569 & 0.3496533 & \\
& Non-member & 6.137374 & 0.0810767 & 0.9246 \\
& Member & 6.018627 & 0.0850244 & \\
& Difference & 0.1187463 & 0.1284262 & \\
\hline
\end{tabular}

Source: Own computation, 2019

Therefore, per unit profits of the two groups are too closer. Test of significance of the difference in per unit profit as indicated by the t-value depicts the similarity in per unit profit between the two groups. Therefore, lucrativeness of the market seems to be not brought about whether farmers are members of agricultural cooperatives or not.

Whatever the case may be, this preliminary result alone does not weigh enough to confirm the nonsignificance impact of cooperatives for profitability of farmers due to the fact that there is no randomization in membership to cooperatives. Therefore, the result should be verified by different methodology which can take into account the non-randomization of treatment. To this end, in the next section, econometric analysis making use of Propensity Score Matching (PSM) method was presented.

\section{Propensity Score Matching Method}

As indicated in the methodology part, we should follow several procedures in the application of PSM. These include, estimation of the propensity scores for all the observations, decision on choice of matching algorithm, making test of overlap assumption, estimation of the Average Treatment Effect on Treated (ATT), and making sensitivity analysis to verify the robustness of the result. Hence, the presentation follows accordingly.

Estimation of the propensity scores

Logistic regression was used to estimate the propensity score for each observation. Before estimation of the logistic regression, test of multicollinearity was carried out using variance inflation factor which shows there is no strong multicollinearity among the variables used for the logistic regression. The result of the logistic regression is presented using Table 3. As indicated in the Table 3, 14 variables were considered as the major determinants of membership to agricultural cooperatives.

\section{Choice of matching algorithm}

After estimation of the propensity score for each observation, we need to choose among the matching algorithms. As indicated in the methodology part, there are mainly three algorithms to consider with their different features/widths. These include Kernel Matching, Caliper Matching, and Nearest Neighbour Matching. Four selection criteria were considered to choose among the matching algorithms. An algorithm with lower Ps $\mathrm{R}^{2}$, larger matched sample size, more number of balanced covariates, and lower mean bias is selected. Accordingly, as indicated in Table 4, Kernel Matching with bandwidth 0.1 was found to be the best matching algorithm based on the mentioned criteria.

Along with the choice of the matching algorithm, result of the balancing tests of covariates using the chosen algorithm was also reported using Table 5. As indicated in Table 5, 9 of the covariates and P-score were not balanced (show bias towards one of the groups) before matching. But, after matching, all the covariates were balanced as indicated by the t-test showing that there is no significant difference in the covariates between the two groups.

\section{Test of the overlap assumption}

Among the assumptions of Propensity Score Matching method, the overlap assumption is the one which states that the observations are properly matched in the common support region. This can be tested using graph of the propensity scores for the counterparts of the two groups.

For the sake of overlapping, we need to consider propensity scores in common support region only. In order to identify the common support region, we need to look at the minimum and maximum propensity scores for both groups. The minimum and maximum propensity scores for the treated group are 0.134984 and 0.9957619 , respectively whereas the minimum and maximum propensity scores for the control group are 0.0038383 and 0.8152288 , respectively. Hence, the common support region is between 0.134984 and 0.8152288 . This implies observation with propensity scores lower than 0.134984 and greater than 0.8152288 should be dropped. Accordingly, 49 observations were dropped (40 from control and 9 from treated groups). Graphical test of the overlap assumption, as shown by Figure 1, indicates that there should be observations to be dropped which are in off support region. But, as shown by Figure 2, after finding the common support region, all the observations look overlapped with their counterparts in other group, based on their propensity scores. 
Table 3: Result of the Logistic Regression (Dependent Variable: Membership to Agricultural Cooperatives)

\begin{tabular}{lllrr}
\hline Variable & Coefficients & Std. Err & Z & P-value \\
\hline Sex of household head & -0.137294 & 0.9204022 & -0.15 & 0.881 \\
Age of household head & -0.1258002 & 0.0489251 & -2.57 & 0.010 \\
Education level of household head & 0.3282416 & 0.2923579 & 1.12 & 0.262 \\
Work experience & 0.11996 & 0.0436034 & 2.75 & 0.006 \\
Family size & 0.0818664 & 0.0787382 & 1.04 & 0.298 \\
Dependency ratio & -1.262241 & 0.8619453 & -1.46 & 0.143 \\
Access to credit & -2.997326 & 1.138137 & -2.63 & 0.008 \\
Farm size & 0.4988442 & 0.6078762 & 0.82 & 0.412 \\
Yield & $-9.70 \mathrm{e}-06$ & $9.44 \mathrm{e}-06$ & -1.03 & 0.304 \\
Distance to the nearest market & -0.0627342 & 0.0552213 & -1.14 & 0.256 \\
Proportion of farm income & -3.761311 & 1.402942 & -2.68 & 0.007 \\
Quantity of potato provided to the market & 0.0002553 & 0.0000896 & 2.85 & 0.004 \\
Level of access for market information & 0.2586787 & 0.1832803 & 1.41 & 0.158 \\
Political participation of the household & 0.2588929 & 0.3909519 & 0.66 & 0.508 \\
Cons & 4.048278 & 2.42918 & 1.67 & 0.096 \\
Number of observations & \multicolumn{2}{c}{300} & & \\
LR chi2(14) & 59.00 & & & \\
Prob > chi2 & 0.0000 & & & \\
Pseudo R2 & 0.1534 & & & \\
Log likelihood & -162.81212 & & &
\end{tabular}

Source: Own computation, 2019

Table 4: The Matching Algorithms with their Different Features and the Selection Criteria

\begin{tabular}{|c|c|c|c|c|c|}
\hline $\mathrm{S} / \mathrm{N}$ & Matching algorithm & $\mathrm{Ps}^{2}$ & $\begin{array}{l}\text { Matched sample size } \\
\text { (on support) }\end{array}$ & $\begin{array}{l}\text { No. of balanced } \\
\text { covariates }\end{array}$ & $\begin{array}{l}\text { Mean } \\
\text { bias }\end{array}$ \\
\hline 1 & Kernel normal band width & 0.008 & $\begin{array}{l}\text { total }=251 \\
\text { untreated }=158 \\
\text { treated }=93\end{array}$ & $\begin{array}{l}14 \\
+ \text { the pscore }\end{array}$ & 4.7 \\
\hline 2 & Kernel bandwidth 0.1 & 0.006 & $\begin{array}{l}\text { total }=251 \\
\text { untreated }=158 \\
\text { treated }=93\end{array}$ & $\begin{array}{l}14 \\
+ \text { the pscore }\end{array}$ & 4.1 \\
\hline 3 & Kernel bandwidth 0.25 & 0.016 & $\begin{array}{l}\text { total }=251 \\
\text { untreated }=158 \\
\text { treated }=93\end{array}$ & $\begin{array}{l}14 \\
+ \text { the pscore }\end{array}$ & 6.1 \\
\hline 4 & Kernel bandwidth 0.5 & 0.047 & $\begin{array}{l}\text { total }=251 \\
\text { untreated }=158 \\
\text { treated }=93\end{array}$ & 14 & 11.8 \\
\hline 5 & Caliper Matching Band width 0.01 & 0.012 & $\begin{array}{l}\text { total }=235 \\
\text { untreated }=148 \\
\text { treated }=87\end{array}$ & $\begin{array}{l}14 \\
+ \text { the pscore }\end{array}$ & 4.6 \\
\hline 6 & Caliper Matching Band width 0.25 & 0.025 & $\begin{array}{l}\text { total }=251 \\
\text { untreated }=158 \\
\text { treated }=93\end{array}$ & 14 & 8.1 \\
\hline 7 & Caliper Matching Band width 0.5 & 0.061 & $\begin{array}{l}\text { total }=251 \\
\text { untreated }=158 \\
\text { treated }=93\end{array}$ & 13 & 13.5 \\
\hline 8 & Nearest Neighbor 1 & 0.035 & $\begin{array}{l}\text { total }=251 \\
\text { untreated }=158 \\
\text { treated }=93\end{array}$ & $\begin{array}{l}14 \\
+ \text { the pscore }\end{array}$ & 8.9 \\
\hline 9 & Nearest Neighbor 2 & 0.017 & $\begin{array}{l}\text { total }=251 \\
\text { untreated }=158 \\
\text { treated }=93\end{array}$ & $\begin{array}{l}13 \\
+ \text { the pscore }\end{array}$ & 6.8 \\
\hline 10 & Nearest Neighbor3 & 0.012 & $\begin{array}{l}\text { total }=251 \\
\text { untreated }=158 \\
\text { treated }=93\end{array}$ & $\begin{array}{l}13 \\
+ \text { the pscore }\end{array}$ & 6.2 \\
\hline 11 & Nearest Neighbor4 & 0.014 & $\begin{array}{l}\text { total }=251 \\
\text { untreated }=158 \\
\text { treated }=93\end{array}$ & $\begin{array}{l}14 \\
+ \text { the pscore }\end{array}$ & 7.0 \\
\hline
\end{tabular}

Note: Ps stands for Pseudo

Source: Own computation, 2019 
Table 5: Result of the balancing tests of covariates using the kernel matching estimation with bandwidth 0.1

\begin{tabular}{|c|c|c|c|c|c|c|}
\hline \multirow[t]{2}{*}{ Variables } & \multicolumn{2}{|c|}{ Unmatched Mean } & \multirow[t]{2}{*}{ t-value } & \multicolumn{2}{|c|}{ Matched Mean } & \multirow[t]{2}{*}{ t-value } \\
\hline & Treated & Control & & Treated & Control & \\
\hline Sex of household head & 0.98039 & 0.96465 & 0.76 & 0.97849 & 0.98362 & -0.25 \\
\hline Age of household head & 38.461 & 37.919 & 0.73 & 38.054 & 38.563 & -0.58 \\
\hline Education level of household head & 0.53922 & 0.40909 & 2.15 & 0.52688 & 0.4983 & 0.39 \\
\hline Work experience & 20.598 & 18.717 & 2.41 & 20.204 & 20.521 & -0.35 \\
\hline Family size & 7.598 & 7.1566 & 1.84 & 7.5806 & 7.6042 & -0.08 \\
\hline Dependency ratio & 0.49294 & 0.50463 & -0.50 & 0.4939 & 0.48737 & 0.27 \\
\hline Access to credit & 0.0098 & 0.08081 & -2.54 & 0.01075 & 0.00508 & 0.43 \\
\hline Farm size & 0.4451 & 0.3599 & 2.95 & 0.41694 & 0.42913 & -0.31 \\
\hline Yield & 27356 & 25545 & 0.74 & 26661 & 26244 & 0.15 \\
\hline Distance to the nearest market & 5.2206 & 5.3425 & -0.38 & 5.0699 & 5.2023 & -0.35 \\
\hline Proportion of farm income & 0.93419 & 0.97878 & -3.24 & 0.96275 & 0.96776 & -0.34 \\
\hline Quantity of potato provided to the market & 4294.5 & 3247 & 3.96 & 3872.5 & 3844.8 & 0.09 \\
\hline Level of access for market information & 3.4804 & 3.197 & 2.91 & 3.4194 & 3.4483 & -0.25 \\
\hline Political participation of the household & 0.23529 & 0.11111 & 2.86 & 0.2043 & 0.17783 & 0.46 \\
\hline P-score & 0.45664 & 0.27991 & 7.80 & 0.41512 & 0.40824 & 0.30 \\
\hline Observations & 102 & 198 & & 93 & 158 & \\
\hline
\end{tabular}

Source: Own computation, 2019

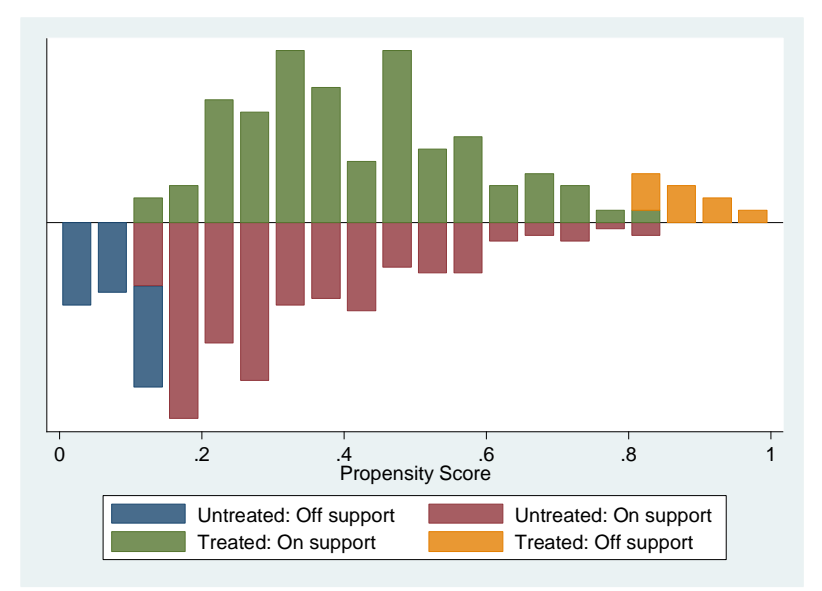

Figure 1: Histogram of propensity score distribution and common support

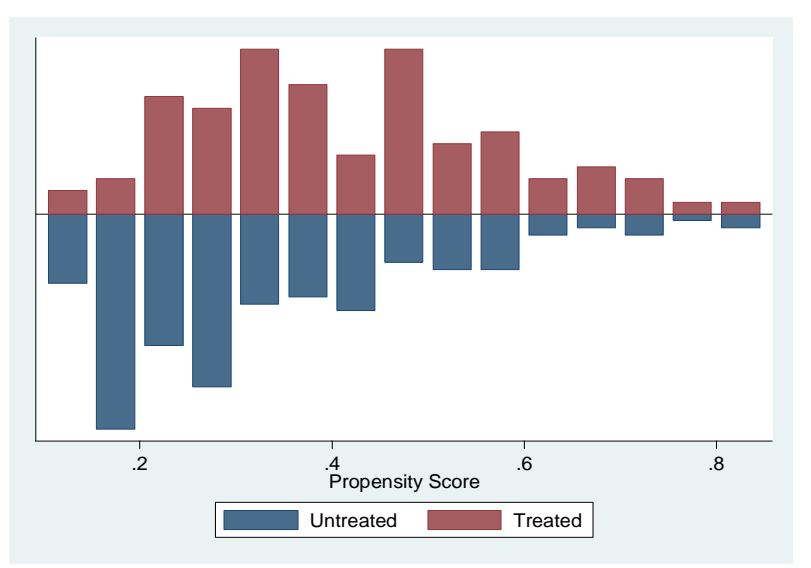

Figure 2: Common support

\section{Average treatment effect on treated (ATT)}

The main aim of this study is to measure the impact of membership in agricultural cooperatives on profitability of farmers. Following the above procedures, after we identify the common support region of the propensity scores, average treatment effect on treated is estimated. The major indicator for the estimation of the average treatment indicator is per unit profit. However, so as to disintegrate the main sources of the difference in profitability, per unit cost of production, per unit cost of marketing and per unit price were taken into account. The result of the estimation of the ATT was reported using Table 6.

Table 6 shows that, for all the outcome variables, there is no significant difference between the two groups, at 5\% level of significance. However, in terms of per unit cost of production, the impact is marginally significant at $10 \%$ level of significance, in favour of non-members. Generally, the implication of this result is that membership to agricultural cooperatives does not bring about any better benefits (in terms of profitability), even it may be worse for members in terms of cost of production.

This result supports the findings of Hun et al (20018) and Ofori et al (2019) who have found that membership to agricultural cooperatives may not guarantee relatively better agricultural income. The former study reveals that agricultural cooperatives have no impact on paddy yields and paddy revenue in Takeo Province of Cambodia due to the fact that agricultural cooperatives do not provide sufficient training to their members, and members did not actively attend those trainings provided. Result of the later study also indicate that membership of commercial vegetable cooperatives has no effect on agricultural incomes or the value or amounts of agricultural inputs in Cambodia.

In contrast to the result of this study, Abate et al (2014) have found that membership to agricultural cooperatives can increase their technical efficiency as compared to non-members; whereas Ahmed and Mesfin (2017) have indicated that membership to cooperatives has the tendency to improve the wellbeing of smallholder farmers. However, these studies' perspectives are not related to the market. Even if cooperatives are efficient in 
technical aspects, the outcome may be changed by the interplay of the market. The market outcome may be related to the quality of the product. Francesconi \& Ruben (2012), comparing production of milk between cooperative and non-cooperative enterprises in Ethiopia, they found cooperatives to be more productive, but that quality was lower. Cooperatives may encourage inputs and intensive practices which are not beneficial to production quality. In turn, quality really matter in determining the price and revenue. Moreover, the efficiency of cooperatives can be determined by their social capital and governance structure. Ruben and Heras (2012) have found that, in Sidama Zone of Ethiopia, some cooperatives are efficient in many aspects whereas others fail to achieve their targeted goal due to weak social capital and governance structure. From this, we can understand that not all cooperatives are successful. The justification behind this may be, membership to agricultural cooperatives, in the study areas, distracts the members from looking for better options of input supply, given that the cooperatives are functioning inefficiently. During the Focus Group Discussion, development agents complain that the cooperative union is inefficient in provision of input supply. In addition, it was found that the cooperatives are not functional in some observable aspects. For instance, the cooperatives are little operational in marketing activities, specially, in Kombolcha. In this regard, the Haramaya Cooperatives Union is relatively better.

Amazingly, it was found that choosing Cooperative Union as one of choice of market outlets has significant positive effect for profitability of the farmers (through reduction of marketing costs and getting better price). As indicated in Table 7, per unit profit of those who choose Cooperative Union as one of their market outlet is significantly higher than those who don't choose it.

However, only 44 (43\%) of the total 102 sample members of cooperatives are enjoying this benefit (we should also note that non-members of agricultural cooperatives have the chance to use the Cooperative Union as market outlet). From our survey, 14 (7\%) of the 198 sample non-members used Cooperative Union as one of their market outlet. Besides, several challenges were raised by the member respondents against the agricultural cooperatives. These were mentioned with their rank of severity in the next section of this paper.

\section{Sensitivity analysis}

The sensitivity analysis was carried out making use of the slightly significant outcome variable (per unit cost of production) as the centre of analysis (note that all the other outcome variables are components of per unit profit). As indicated in the methodology part, simulation-based sensitivity analysis was undertaken. The detail procedure of the method was explained in the methodology part. In this method, a simulation confounder $(U)$ is created as a covariate factor for deviation from Conditional Independence Assumption (CIA) so that comparison is made between the ATTs without the simulated confounder and with simulated confounder. The extent of deviation of the ATT with simulated confounder away from the baseline ATT portrays the robustness of the result.

The ATT with simulated confounder is estimated in consideration of different possibilities of $d\left(=P_{01}-P_{00}\right)$ and $s\left(=P_{1}-P_{0}\right)$ which were defined in the methodology part. Accordingly, we present, in correspondence to different values of the parameters $d$ and $s$, the estimated ATT, and the values of the parameters $\Gamma$ and $\Lambda$, which measure the effect of the simulated confounder $U$ on the outcome and on the treatment, respectively, controlling for the observed confounders.

As indicated in Table 8, based on Kernel Matching Algorithm, the result shows that, except in some few extreme cases, the percentage of deviation of the value of the ATT with simulated confounder away from the baseline ATT is fairly lower. As supplementary tool of analysis, we have used another algorithm (Nearest Neighbour Matching), for which appropriate standard errors with multiple imputation can be produced using STATA software, so as to see the robustness of the significance of the ATT with and without simulated confounder. The result shows that, almost in all cases, the ratios of the ATTs to their respective standard errors are slightly higher which confirm the slightly significance of per unit cost of production (see appendix). Therefore, in both cases, it can be concluded that our estimation is robust with consideration of unobserved covariates.

Table 6: Average Treatment Effect on Treated (ATT)

\begin{tabular}{llrrr}
\hline Outcome variable & Treated & Control & Difference & t-value \\
\hline Per unit profit & 3.95107532 & 4.20618533 & -0.255110017 & -1.63 \\
Per unit cost of production & 1.58025993 & 1.37630394 & 0.203955989 & 1.93 \\
Per unit marketing cost & 1.00039349 & 0.543047056 & 0.457346439 & 0.86 \\
Per unit price & 5.94623656 & 6.12394112 & -0.177704558 & -1.34 \\
\hline
\end{tabular}

Source: Own computation, 2019

Table 7: Comparison of Per Unit Profit between Choosing and Not Choosing Cooperative Union as Market Outlet

\begin{tabular}{llrll}
\hline Variable & Group & Mean & Std. Err & t-value \\
\hline Per unit profit & Do not choose & 3.995048 & 0.0774443 & -3.7015 \\
& Choose & 4.64193 & 0.1454494 & \\
& Difference & -0.6468814 & 0.1747643 & \\
\hline
\end{tabular}

Source: Own Computation, 2019 
Table 8: Sensitivity Analysis using Kernel Matching Algorithm

Values of ATT with simulated confounder

$\mathrm{S}=-0.3 \quad \mathrm{~S}=-0.2 \quad \mathrm{~S}=-0.1 \quad \mathrm{~S}=0.1 \quad \mathrm{~S}=0.2 \quad \mathrm{~S}=0.3 \quad$ without

simulated

confounder using

Kernel Matching

\begin{tabular}{|c|c|c|c|c|c|c|c|}
\hline \multirow[t]{4}{*}{$d=-0.3$} & 0.198 & 0.210 & $0.227(6 \%)$ & 0.269 & 0.295 & 0.326 & 0.241 \\
\hline & $(18 \%)$ & $(13 \%)$ & $\Gamma=0.266$ & $(12 \%)$ & $(22 \%)$ & $(35 \%)$ & \\
\hline & $\Gamma=0.266$ & $\Gamma=0.266$ & $\Lambda=0.664$ & $\Gamma=0.265$ & $\Gamma=0.255$ & $\Gamma=0.259$ & \\
\hline & $\Lambda=0.244$ & $\Lambda=0.419$ & & $\Lambda=1.642$ & $\Lambda=2.632$ & $\Lambda=5.886$ & \\
\hline \multirow[t]{4}{*}{$\mathrm{d}=-0.2$} & 0.219 & 0.224 & 0.235 & 0.259 & 0.284 & 0.298 & 0.241 \\
\hline & $(9 \%)$ & $(7 \%)$ & $(2 \%)$ & $(7 \%)$ & $(18 \%)$ & $(24 \%)$ & \\
\hline & $\Gamma=0.449$ & $\Gamma=0.411$ & $\Gamma=0.436$ & $\Gamma=0.450$ & $\Gamma=0.402$ & $\Gamma=0.455$ & \\
\hline & $\Lambda=0.220$ & $\Lambda=0.394$ & $\Lambda=0.626$ & $\Lambda=1.605$ & $\Lambda=2.516$ & $\Lambda=4.549$ & \\
\hline \multirow{4}{*}{$d=-0.1$} & 0.240 & 0.240 & 0.243 & 0.257 & 0.271 & 0.286 & 0.241 \\
\hline & $(0.4 \%)$ & $(0.4 \%)$ & $(0.8 \%)$ & $(7 \%)$ & $(12 \%)$ & $(19 \%)$ & \\
\hline & $\Gamma=0.693$ & $\Gamma=0.697$ & $\Gamma=0.703$ & $\Gamma=0.648$ & $\Gamma=0.683$ & $\Gamma=0.653$ & \\
\hline & $\Lambda=0.219$ & $\Lambda=0.410$ & $\Lambda=0.685$ & $\Lambda=1.628$ & $\Lambda=2.478$ & $\Lambda=4.398$ & \\
\hline \multirow[t]{4}{*}{$\mathrm{d}=0.1$} & 0.276 & 0.241 & 0.242 & 0.256 & 0.270 & 0.282 & 0.241 \\
\hline & $(15 \%)$ & $(0 \%)$ & $(0.4 \%)$ & $(6 \%)$ & $(12 \%)$ & $(17 \%)$ & \\
\hline & $\Gamma=1.714$ & $\Gamma=0.705$ & $\Gamma=0.713$ & $\Gamma=0.672$ & $\Gamma=0.676$ & $\Gamma=0.705$ & \\
\hline & $\Lambda=0.221$ & $\Lambda=0.419$ & $\Lambda=0.700$ & $\Lambda=1.625$ & $\Lambda=2.617$ & $\Lambda=4.460$ & \\
\hline \multirow[t]{4}{*}{$\mathrm{d}=0.2$} & 0.299 & 0.279 & 0.257 & 0.235 & 0.228 & 0.220 & 0.241 \\
\hline & $(24 \%)$ & $(16 \%)$ & $(7 \%)$ & $(2 \%)$ & $(5 \%)$ & $(9 \%)$ & \\
\hline & $\Gamma=2.630$ & $\Gamma=2.423$ & $\Gamma=2.457$ & $\Gamma=2.673$ & $\Gamma=2.698$ & $\Gamma=2.555$ & \\
\hline & $\Lambda=0.242$ & $\Lambda=0.451$ & $\Lambda=0.666$ & $\Lambda=1.816$ & $\Lambda=2.624$ & $\Lambda=4.715$ & \\
\hline \multirow[t]{4}{*}{$d=0.3$} & 0.311 & 0.290 & 0.262 & 0.224 & 0.214 & $0.188(22 \%)$ & 0.241 \\
\hline & $(29 \%)$ & $(20 \%)$ & $(9 \%)$ & $(7 \%)$ & $(11 \%)$ & $\Gamma=4.315$ & \\
\hline & $\Gamma=4.249$ & $\Gamma=4.279$ & $\Gamma=4.131$ & $\Gamma=4.373$ & $\Gamma=4.144$ & $\Lambda=7.276$ & \\
\hline & $\Lambda=0.303$ & $\Lambda=0.471$ & $\Lambda=0.735$ & $\Lambda=1.818$ & $\Lambda=3.292$ & & \\
\hline
\end{tabular}

Note: Values in parentheses are percentages of deviations of the ATT with simulated confounder from the baseline ATT

Source: Own computation, 2019

Table 9: Challenges Facing the Agricultural Cooperatives with their Rank of Severity

\begin{tabular}{|c|c|c|c|c|c|}
\hline Challenges & Mean Scale & Rank & Min & Max & \\
\hline Lack of good management system & 4.10101 & 1 & & 1 & 5 \\
\hline Lack of Coordination & 4.040404 & 2 & & 1 & 5 \\
\hline Problem of participation and commitment of members & 4 & 3 & & 1 & 5 \\
\hline Lack of education or skilled human resource & 3.949495 & 4 & & 1 & 5 \\
\hline Lack of technology based system & 3.919192 & 5 & & 1 & 5 \\
\hline Competition and absence of well-developed competitive strategy & 3.858586 & 6 & & 1 & 5 \\
\hline $\begin{array}{l}\text { Lack of well-developed market infrastructures such as communication } \\
\text { and transportation }\end{array}$ & 3.848485 & 7 & & 1 & 5 \\
\hline Shortage of capital & 3.787879 & 8 & & 1 & 5 \\
\hline Lack of external assistance & 3.666667 & 9 & & 1 & 5 \\
\hline Absence of good governance structure & 3.646465 & 10 & & 1 & 5 \\
\hline Lower business volume (scale) & 3.646465 & 11 & & 1 & 5 \\
\hline High transaction cost & 3.636364 & 12 & & 1 & 5 \\
\hline Operational problems & 3.616162 & 13 & & 1 & 5 \\
\hline Market risk & 3.585859 & 14 & & 1 & 5 \\
\hline Limited access to credit & 3.565657 & 15 & & 1 & 5 \\
\hline Absence of homogeneity of products & 3.464646 & 16 & & 1 & 5 \\
\hline Customers inability to pay & 3.414141 & 17 & & 1 & 5 \\
\hline \multicolumn{6}{|l|}{ Accounts (credit) and cash flow problems. } \\
\hline Obstacle of government policies and regulatory framework & 3.353535 & 18 & & 1 & 5 \\
\hline Low quality of the products & 3.343434 & 19 & & 1 & 5 \\
\hline
\end{tabular}

Source: Own computation, 2019

\section{Challenges Facing Agricultural Cooperatives}

Performance efficiency of the agricultural cooperatives in the study areas are believed to be compromised by a number of factors. Among which, the major ones were listed down based on their rank of severity in Table 9. During the survey, the sample respondents under 
membership of the agricultural cooperatives were asked to mention the major challenges facing the agricultural cooperatives and rate the extent of their severity using Likert type scaling (with five categories of order).

Based on their rating, the most severe ones with highest rate of severity include lack of good management system, lack of coordination, and problem of participation and commitment of members. In addition, lack of educated/skilled man power, lack of technical based system, competition and absence of well-developed competitive strategy, lack of well-developed market infrastructures such as communication and transportation, shortage of capital, lack of external assistance, absence of good governance structure, lower business volume (scale), high transaction cost, operational problems, market risk, and limited access to credit were also found to be considerable problems, respectively, in descending order of severity. Absence of homogeneity of products, customers' inability to pay accounts (credit) and cash flow problems, obstacle of government policies and regulatory framework, and low quality of the products are the least severe challenges.

\section{CONCLUSION AND RECOMMENDATION}

Agricultural cooperatives emerged in pursuit of empowering smallholder farmers through improvement in productivity and enhancing market gain (by reducing marketing cost and chasing better price) against opportunistic traders. Theoretically, several benefits are believed to be generated from agricultural cooperatives. This has been revealed by some empirical studies. In contrast, some other studies deny such positive impact referring to the possibilities of inefficient performance of these organizations in developing countries.

In cognizant of different drawbacks observed against agricultural cooperatives in Ethiopia, this study also intended to figure out the impact of the cooperatives on profitability of member farmers taking the experience of potato growers in Eastern Ethiopia.

The study was conducted using survey data collected from members and non-members of cooperatives from two woredas (Haramaya and Kombolcha) of Eastern Hararghe zone. Focus group discussions were also carried out for supplementary information. The study involved both descriptive and quantitative analyses. The quantitative analysis focused on Propensity Score Matching (PSM) method to measure the impact of the cooperatives on net gain of its members. The robustness of the result of the PSM was verified using simulated based sensitivity analysis.

Result of the descriptive analysis indicated, there is insignificant difference of per unit profit between members and non-members of agricultural cooperatives. This was also confirmed through disintegration of components of profitability. That is, there is no significant difference in per unit price, per unit cost of production, and per unit cost of marketing between members and nonmembers.

After following the standard procedures of PSM method (estimation of the propensity scores for each observation, selection of matching algorithm and test of balancing, test of the overlap assumption, and the sensitivity analysis), Average Treatment effect on Treated (ATT) for per unit profit was estimated which shows that there is no significant difference between members and non-members in this regard. The same holds true for per unit price, per unit cost of production, and per unit cost of marketing, except the marginal significance (at $10 \%$ level) for per unit cost of production in favour of non-members. The implication of this result is that membership to agricultural cooperatives does not have any positive impact in terms of profitability of the farmers.

The justification behind this result is that the existing agricultural cooperatives are little operational on activities attached to profitability of member farmers. This has the tendency to distract farmers not to look for better options of production and marketing. For instance, some cooperatives are hardly involved in marketing activities. The result shows that only few proportion of member farmers are enjoying sale of their outputs via agricultural Cooperative Union even if it is profitable to use the Cooperative Union as market outlet. Inactive participation of some members of the cooperatives can also be the reason for this.

In addition, several challenges are raised against the agricultural cooperatives. The most severe ones with highest scale of severity include lack of good management system, lack of coordination, and problem of participation and commitment of members. In addition, lack of educated/skilled man power, lack of technical based system, competition and absence of well-developed competitive strategy, lack of well-developed market infrastructures such as communication and transportation, shortage of capital, lack of external assistance, absence of good governance structure, lower business volume (scale), high transaction cost, operational problems, market risk, and limited access to credit were also found to be considerable problems, respectively, in descending order of severity.

Based on these results, it is recommended that there should be strict follow-up on cooperatives and their performance by the concerned entity; all agricultural cooperatives should be well functional in all aspects attached to profitability of farmers such as marketing activities and provision of productive input supply; there should be frequent and regular awareness creation to enhance active participation of member farmers; frequent and regular trainings are also necessitated in order to build the managerial capacity of the leaders; and there should be clear framework of coordination in production and marketing activities.

Moreover, we should take into account for provision of skilled man power, creation of technical based system (may be as in the case Ethiopian Commodity Exchange), developing well framed competitive strategy, improving market infrastructures such as communication and transportation, provision of capital, creating link for external assistance, improving good governance structure, increasing the business volume (scale), reduction of transaction cost, reducing operational problems, reducing market risks, and provision of better access to credit. 
Acknowledgments: We would like to thank Ethiopian Mistry of Science and Higher Education for the $\mathrm{PhD}$ study. Would also like to express our sincere gratitude for the reviewers and editorial board of the journal.

\section{REFERENCES}

ABATE, G. T., FRANCESCONI, G. N., \& GETNET K. (2014). Impact of agricultural cooperatives on smallholders' technical efficiency: empirical evidence from Ethiopia. Annals of Public and Cooperative $\begin{array}{lllll}\text { Economics. } & 85(2) . & 257 & - & 286 .\end{array}$ https://doi.org/10.1111/apce.12035

ADANE, H., MEUWISSEN, M. P. M., TESFAYE, A., LOMMEN, W. J. M., LANSINK, A. O., TSEGAYE, A., \& STRUIK, P. C. (2010). analysis of seed potato systems in Ethiopia. American Potato Research Journal. $\quad 87(6)$ 537-552. http://doi.org/10.1007/s12230-010-9164-1

AHMED, M. H., \& MESFIN, H. M. (2017). The impact of agricultural cooperatives membership on the wellbeing of smallholder farmers: empirical evidence from Eastern Ethiopia. Agricultural and Food Economics. 5(1). 1-13. http://doi.org/10.1186/s40100$\underline{017-0075-\mathrm{Z}}$

ARGAW, Y. A. (2019). The role of Agricultural cooperatives in accessing input and output markets: An overview of experiences of SRFCF, SNNPR, Ethiopia. Southern Region Farmers' Cooperative Federation.

http://www.fao.org/fileadmin/templates/gender/docs/ Speech_IYC.pdf

ARPINO, B., \& AASSVE, A. (2013). Estimating the causal effect of fertility on economic wellbeing: data requirements, identifying assumptions and estimation methods. Empirical Economics. 44(1) .355-385. http://doi.org/10.1007/s00181-010-0356-9

BARKER, W. J. (1990). Agricultural marketing. Second Edition. Oxford University Press. United Kingdom. https://www.worldcat.org/title/agriculturalmarketing/oclc/20168111

BARRETT, C. B., \& LI, J. R. (2002). Distinguishing between equilibrium and integration in spatial price analysis. American Journal of Agricultural Economics. $\quad$ 84(2). 292-307. http://doi.org/10.1111/1467-8276.00298

BERNARD, T., TAFFESSE, A. S., \& GABREMADHIN, E. (2008). Impact of cooperatives on smallholders' commercialization behavior: evidence from Ethiopia. Journal of Agricultural Economics. 39(2). 147-161. https://doi.org/10.1111/j.15740862.2008.00324.X

BIENABE, E., \& SAUTIER, D. (2006). The role of small scale producers organizations to address market access. Paper presented at the International Seminar Beyond Agriculture: Making Markets Work for the Poor, Church House Conference Centre, Westminster, London, UK, 16 pp. https://www.gov.uk/research-fordevelopment-outputs/the-role-of-small-scaleproducers-organizations-to-address-market-access

BLOKLAND, K., \& GOUET, C. (2007). Peer to peer farmer support for economic development. In G. TON,
J. BIJMAN \& J. OORTHUIZEN (Eds), Producer Organizations and Market Chain (pp. 71-90). Wageningen Academic Publishers. http://doi.org/10.3920/978-90-8686-623-6

BRANSON, R. E., \& DAUGLASS, G. N. 1983. Introduction to agricultural marketing. American Journal of Agricultural Economics. 65(4). 837 - 838. https://doi.org/10.2307/1240482

CALIENDO, M., \& KOPEINING, S. (2005). Some practical guidance for implementation of propensity score matching. Discussion Papers. German Institute for Economic Research. https://www.diw.de/documents/dokumentenarchiv/17 143214/dp485.pdf

CHADDAD, F., COOK, M. L., \& HECKELEI, T. (2005). Testing for the presence of financial constraints in US agricultural cooperatives: an investment behavior approach. Journal of Agricultural Economics. 56(3), 385-397. 9552.2005.00027.x

https://doi.org/10.1111/j.1477-

DEHEJIA, R., \& WAHBA, S. (2012). Causal effects in non-experimental studies: re-evaluating the evaluation of training programs. Journal of the American Statistical Association. 94(448), 1053-1062. https://doi.org/10.2307/2669919

DEBELA, M., DIRIBA, S., \& BEKELE, H. (2018). Impact of cooperatives membership on economy in Eastern Oromia: the case of Haramaya agricultural farmers' cooperative union (HAFCU). Annals of Public and Cooperative Economics. 89(2), 361-376. https://doi.org/10.1111/apce.12175

FRANCESCONI, G. N., \& RUBEN R. (2012). The hidden impact of cooperative membership on quality management: a case study from the dairy belt of Addis Ababa. Journal of Entrepreneurial and Organizational Diversity. 1(1). 85-103. https://econpapers.repec.org/article/trncsnjrn/v_3a1_3 ai_3a1_3ap_3a85-103.htm

GABRE-MADHIN, E. Z. (2001). Market institutions, transaction costs, and social capital in the Ethiopian grain market. Research Report 124, IFPRI, Washington,

D.C. https://www.ifpri.org/publication/market-institutionstransaction-costs-and-social-capital-ethiopian-grainmarket

GABRE-MADHIN, E. Z., \& HAGGBLADE, S. (2004). Successes in African agriculture: results of an expert survey. World Development. 32(5). 745-766. https://doi.org/10.1016/j.worlddev.2003.11.004

HABTEWOLD, A. B., \& CHALLA, T. M. (2019). Challenges and opportunities for smallholder farmers participation in teff market in Ambo District, West Shoa Zone of Oromia, Ethiopia. International Journal of Business and Social Science. 10(8). 42 - 48. http://doi.org/10.30845/ijbss.v10n8p5

GETNET, K., VERBEKE, W., \& VIAENE, J. (2005). Modeling spatial price transmission in the grain markets of Ethiopia with an application of ARDL approach to white teff. Agricultural Economics. 33(s3). 491-502. $\quad$ https://doi.org/10.1111/j.15740864.2005.00469.x 
HENDRIKSE, G. W. J., \& VEERMAN, C. P. (2000). Marketing cooperatives and financial structure: a transaction costs economics analysis. ERIM Report Series Research in Management. https://citeseerx.ist.psu.edu/viewdoc/download?doi=1 $0.1 .1 .1072 .1583 \&$ rep $=$ rep $1 \&$ type $=$ pdf

HUN, S., ITO, S., ISODA, H., \& AMEKAWA, Y. (2018). Impacts of agricultural cooperatives on farmers' revenues in Cambodia: A case study of Tram Kak District, Takeo Province. Journal of Agricultural $\begin{array}{lllll}\text { Science. } & 10(2) . & 82 & - & 88 .\end{array}$ https://doi.org/10.5539/jas.v10n2p82

ICHINO, A., MEALLI, F., \& NANNICINI, T. (2006). From temporary help jobs to permanent employment: what can we learn from matching estimators and their sensitivity? IZA Discussion Paper No. 2149 May 2006. http://ftp.iza.org/dp2149.pdf

IMBENS, G., \& WOOLDRIDGE, J. (2009). Recent developments in the econometrics of program evaluation. Journal of Economic Literature. 47(1). 5 86. http://doi.org/10.1257/jel.47.1.5

KODAMA, Y. (2009). The effects of fair trade on coffee producers: a case study of Ethiopian coffee cooperatives. In S. Ege, H. Aspen, B. Teferra \& S. Bekele (Eds), Proceedings of the 16th International Conference of Ethiopian Studies (pp. 779 - 792). Norwegian University of Science and Technology, Trondheim.

https://zethio.files.wordpress.com/2014/04/ethiopianstudies-volume-3.pdf

KUMA, B., BAKER, D., GETNET, K., \& KASSA, B. (2013). Factors affecting milk market outlet choices in Wolaita zone, Ethiopia. African Journal of Agricultural Marketing. 1(2). $024 \quad$ - 031. https://www.internationalscholarsjournals.com/article s/factors-affecting-milk-market-outlet-choices-inwolaita-zone-ethiopia.pdf

LANEHART, R. E., RODRIGUEZ, P., KIM E. S., BELlARA, A. P., KROMREY, J. D., \& LEE, R. S. (2012). Propensity score analysis and assessment of propensity score approaches using SAS procedures. Statistical and data analysis, Paper 314, SAS Global Forum 2012. https://support.sas.com/resources/papers/proceedings 12/314-2012.pdf

LI, L., SHEN, C., WU, A. C., \& LI, X. (2011). Propensity score-based sensitivity analysis method for uncontrolled confounding. American Journal of Epidemiology. 174(3). 345-353. http://doi.org/10.1093/aje/kwr096

LLEBANI, O. A. (2010). Improving marketing and traceability of agricultural commodities: the role of cooperatives. nigerian strategy support program, policy note No. 26; IFPRI. https://ebrary.ifpri.org/digital/collection/p15738coll2/ $\underline{\mathrm{id} / 4890 /}$

MATOUSA, P., TODOB, Y., \& MOJOC, D. (2013). Roles of extension and ethno-religious networks in acceptance of resource-conserving agriculture among Ethiopian farmers. International Journal of Agricultural Sustainability 11(4), 301-316. https://doi.org/10.1080/14735903.2012.751701
MSPII (Ministry of Statistics and Program Implementation in India) (2010). Manual on agricultural prices and marketing. CSO-MAP, Sansad Marg, New Delhi, October, 2010. http://mospi.nic.in/sites/default/files/publication_repo rts/manual_agr_price_mark_25oct10_0.pdf.

NANNICINI, T. (2007). Simulation-based sensitivity analysis for matching estimators. Stata Journal, 7(3). 334-350. http://doi.org/10.1177/1536867X0700700303

NJUKI, J., KAARIA, S., SANGINGA, P., KAGANZI, E., \& MAGOMBO, T. (2015). Empowering communities through market led development: community agroenterprise experiences from Uganda and Malawi. Papers presented. Future Agricultures Consortium; Institute of Development Studies (IDS), Sussex, GB. 13 p. https://hdl.handle.net/10568/56180

OFORI, E., SAMPSON, G. S., \& VIPHAM, J. (2019). The effects of agricultural cooperatives on smallholder livelihoods and agricultural performance in Cambodia. A United Nations Sustainable Development Journal. 43(4). 218 - 229. https://doi.org/10.1111/1477$\underline{8947.12180}$

ORTMANN, G. F., \& KING, R. P. (2007). Agricultural cooperatives i: history, theory and problems. Agrekon. 46(1). 18

https://doi.org/10.1080/03031853.2007.9523760

PIGUET, F. (2003). Ethiopia: Hararghe \& Shinille zone food security assessment Report. UN Office for the Coordination of Humanitarian Affairs. https://reliefweb.int/report/ethiopia/ethiopiahararghe-shinille-zone-food-security-assessment

ROSENBAUM, P. (1987). Sensitivity analysis to certain permutation inferences in matched observational studies. Biometrika. 74(1). 13-26. https://doi.org/10.2307/2336017

ROSENBAUM, P., \& RUBIN, D. B. (1983). Assessing sensitivity to an unobserved binary covariate in an observational study with binary outcome. Journal of the Royal Statistical Society (Series B) 45. 212-218. https://www.jstor.org/stable/2345524

RUBEN, R., \& HERAS, J. (2012). Social capital, governance and performance of ethiopian coffee cooperatives. Annals of Public and Cooperative Economics. $83(4)$. 463-484. https://doi.org/10.1111/j.1467-8292.2012.00473.x

STAATZ, J. M. 1989. Farmer cooperative theory: recent developments. Research Report 84. U.S. Department of Agriculture; Agricultural Cooperative Service (ACS). https://doi.org/10.22004/ag.econ.52017

THOEMMES, F. J., \& KIM, E. S. (2011). A systematic review of propensity score methods in the social sciences. Multivariate Behavioral Research. 46(1). 90 - 118. https://doi.org/10.1080/00273171.2011.540475

UNDP-EUE (United Nations Development Programme Emergencies Unit for Ethiopia). 1994. Field Trip Report: East and West Hararghe Zones - Region 4 (Oromia), 22 August - 31 August 1994. https://reliefweb.int/report/ethiopia/ethiopiaassessment-field-trip-east-and-west-hararghe-zoneoromiya-region 
ZERSSA, G., FEYSSA, D., KIM, D. G., \& EICHLERLÖBERMANN, B. (2021). Challenges of smallholder farming in ethiopia and opportunities by adopting climate-smart agriculture. Agriculture. 11(3), 192. https://doi.org/10.3390/agriculture11030192 